\title{
Immunomodulation of mice blood cells following treatment with free extract of Lactobacillus acidophilus cell
}

\section{التعديل المناعي لخلايا دم الفئران البيض بعد المعاملة بالمستخلص الخالي من الخلايا لبكتريا حامض اللاكتيك التعايشية النوع Lactobacillus acidophilus}

\author{
Ebtehal H.Al-Naimy Ruqaya M. Al-Ezy* Maysaa C. Al-Yas* \\ Muthanna A. S. Al- Mahdawii \\ Biotechnology Research Center / Al -Nahrain University. \\ *Biotechnology Department /College of Science/ Al -Nahrain University. \\ **Microbiology Department/ College of Science/Diyala University.
المهداوي، مثنى عبد القادر **
ألعزي، رقيه محمد* الياس،ميساء جاسب
النعيمي،ابتهال حسين
مركز بحوث التقنيات الأحيائيه/جامعة النهرين.

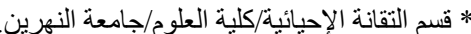

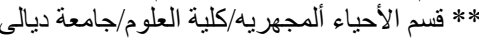

\begin{abstract}
2

study aimed to examine immunomodulatory effect of concentrated cell free

filtrate (CCF) of Lactobacillus acidophilus on immune system of mice by detecting the total and absolute counts of leucocytes. It was shown that CCF of Lactobacillus acidophilus caused a significant increase in total leucocyte count for all concentrations used in comparison with negative control. However, in absolute leucocyte counts the, CCF of $L$. acidophilus at doses $(500,750) \mathrm{mg} / \mathrm{kg}$ caused a significant increase in lymphocyte, neutrophil and monocyte counts, while there was no significant differences in eosinophil's and basophil cells number of mice treated with bacterial filtrate. The interaction study showed that the post-treatment with CCF of $L$. acidophilus caused a significant increase in total leucocytes count and absolute counts of all types of leucocyte cells except basophils and eosinophil's which showed no significant differences in comparison with pre-treatment.
\end{abstract}

هدفت الدراسة لمعرفة تأثير بكتريا حامض اللاكتيك التعايثية النوع Lactobacillus acidophilus علي التئي

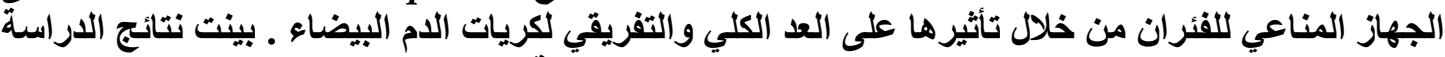

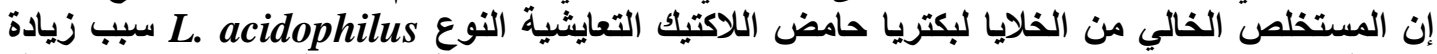

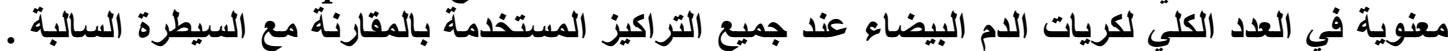

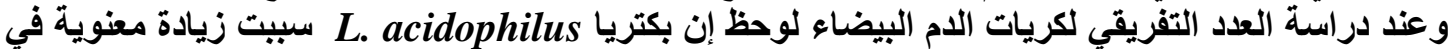

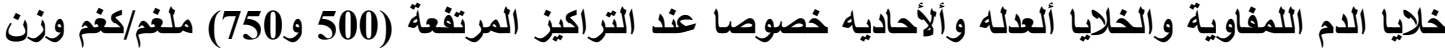

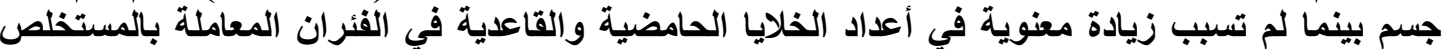

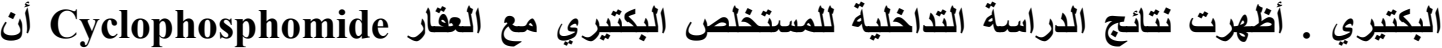

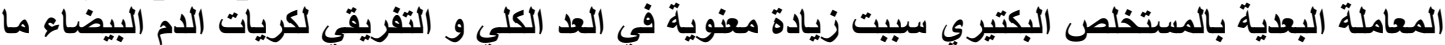

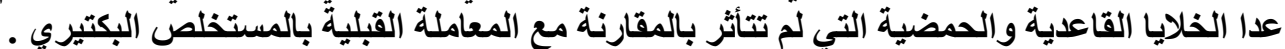

\section{Introduction}

The effectiveness of the immune defense system is adversely affected by ageing, contributing to reduced disease resistance and life expectancy [1]. This biological phenomena, named immunosenescence, could be partially restrained by consuming probiotics [2], since the lactic acid bacteria (LAB) has been related to immunomodulatory and antitumor effects $[3,4]$. Lactic acid bacteria have been proposed as an adjuvant to nutritional therapy of an experimental model of malnutrition, due to their proposed ability to protect against pathogenic agents [2]. The beneficial effects of probiotics seem to be mediated by bacterial interactions with the mucosa, which induce changes in cytokine production in a strain-specific way [1]. 
Also, lactic acid bacteria release bioactive peptides that could modulate the cellular immune response [5]. Therefore, some strains of lactic acid bacteria have been shown to be health promoters by increasing immune function through microflora stabilization, but there are no confluent conclusions about it [6]. Immunomodulation has been observed after administration of LAB in several animal studies [8], but in few human studies $[9,10]$. LAB may enhance the nonspecific resistance of the host to infections and tumors [7] or act as adjuvants of specific immune responses [11, 12]. These activities have been observed after LAB intake by oral and parenteral administration [11]. In our study the immunomodulatory effects of LAB has been explored on mice blood cell following treatment with concentrated cell free filtrate (CCF) of Lactobacillus acidophilus.

\section{Materials and methods}

\section{Laboratory Animals}

Albino male mice Mus musculus (obtained from Biotechnology Research Center-AlNahrain University) were used to carry out the investigated parameters of the present study. Their age range was (8-9) weeks, and their weight was 23-27 grams at the beginning of experiments. The temperature was $23-26^{\circ} \mathrm{C}$, and a light: dark periods of 10:14 hours/day. The diet (standard pellets) and drinking water offered (ad libitium) during all experiments.

\section{Experimental Design}

Three doses $(250,500$, and 750$) \mathrm{mg} / \mathrm{kg}$ of concentrated cell free filtrate (CCF) of Lactobacillus acidophilus were carried out to assess their immunological effects and its modulating action on the effects of cyclophosphomide drug in albino male mice, therefore, such evaluations were carried out through two stages.

First Stage: In this stage, the Immunological effects of three doses of CCF and cyclophosphomide were investigated. Therefore, the animals were divided into three groups:

Group I: The animals were treated with distilled water (negative controls $=8$ animals).

Group II: The animals were treated with cyclophosphomide at a dose of $15 \mathrm{mg} / \mathrm{kg}$ (positive controls $=8$ animals)

Group III: The animals were treated with three doses $(250,500$, and 750$) \mathrm{mg} / \mathrm{kg}$ of CCF of L. acidophilus (24 animals)

The tested materials were administrated orally as a single dose $(0.1 \mathrm{ml})$ per a day for 7 days. Then the mice were sacrificed in day 8 for laboratory assessments.

Second Stage: In this stage, interactions (pre- and post-treatments) between the ideal dose $250 \mathrm{mg} / \mathrm{kg}$ of CCF of L. acidophilus and cyclophosphomide $15 \mathrm{mg} / \mathrm{kg}$ were carried out. The criterion for selection of the ideal dose was based on the approximation between the values of total leucocytes count in the animals treated with CCF of L. acidophilus and the negative control.

1. In pre-treatment interaction: The $\mathrm{CCF}$ was given for 6 days (single dose/day), while cyclophosphomide was given in day 7 , and then animals were sacrificed in day 8 for laboratory assessments.

2. In post-treatment interaction: The animals was given cyclophosphomide on day one, while the (CCF) of L. acidophilus was given in day 2 till day 7 (single dose/day), and then animals were sacrificed in day 8 for laboratory assessments.

Total and Absolute Counts of Leucocytes

Both counts were carried out on blood obtained by heart puncture using insulin disposable syringe $(1 \mathrm{ml})$ precoated with heparin. 


\section{Total Count of Leucocytes}

The conventional method of blood cell counting was employed [13]. A volume of $0.02 \mathrm{ml}$ blood was dispensed in a test tube containing $0.38 \mathrm{ml}$ of leucocyte diluent solution, and then the contents were mixed and the tube was left for three minutes. One drop of the diluted blood was applied to the surface of a counting chamber (Neubauer hemocytometer) under the cover slip. After that, the chamber was left for two minutes to settle the cells, and by then, the leucocytes were counted using the following equation:

Total Count $($ cell/cu.mm.blood $)=$

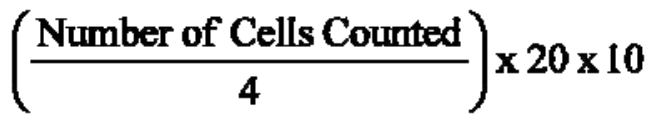

\section{Absolute Count of Leucocytes}

A blood smear was made on a clean slide and left for air drying. Then the slide was stained with Leishman's stain for two minutes and buffered with Leishman's buffer for 10 minutes. After that, the slide was rinsed with tap water and left for air drying [13]. The stained smear was examined under oil immersion power (100X), and at least 200 leucocytes were randomly counted. Then, the percentage of each cell type was obtained. The count of each type of leucocytes was calculated according to the following equation:

Total Count (cell/cu. mm. blood $)=$

$$
\left(\frac{\text { Percentage of Cells x Total Count }}{100}\right)
$$

\section{Preparation of $L$. acidophilus concentrated filtrate}

An liquot (1\%) of L. acidophilus culture was incubated anaerobically at $37^{\circ} \mathrm{C}$ for different periods of time $(24,48,72) \mathrm{hr}$. After the incubation period, the culture was centrifuged at $6000 \mathrm{rpm}$ for $15 \mathrm{~min}$ and the supernatant was obtained [14], and concentrated filtrates of $L$. acidophilus were prepared by freeze-dryer (lyophilizer). Three doses of $L$. acidophilus concentrated filtrate $(250,500$, and 750$) \mathrm{mg} / \mathrm{kg}$ were prepared to assess the immunological effects of cell free supernatant extracts in modulating the effects of the drug cyclophosphomide in albino male mice.

\section{Results}

\section{- Immunological effects of (CCF) of L. acidophilus:}

\section{Total count of leucocytes:}

The second and third doses $(500,750) \mathrm{mg} / \mathrm{kg}$ of CCF were effective in causing a significant increase in total count of leucocytes (16850 and 19850 cell/cu.mm.blood respectively), while none significant increase was shown with the first dose (12300 cell/cu.mm.blood) as compared to the corresponding negative control (8050 cell/cu.mm. blood).

A non-significant increase in total leucocyte count was shown in mice treated cyclophosphomide (positive control) in comparison with negative control (11700 vs. 8050 cell/cu. mm .blood) Table (1). 
Table (1): Total leucocyte count (mean \pm standard error) in albino male mice treated with Lactobacillus acidophilus concentrated filtrate, distilled water (negative controls) and cyclophosphomide drug (positive control).

\begin{tabular}{|c|c|c|c|c|}
\hline Groups & $\begin{array}{c}\text { Doses } \\
\text { (mg/kg) }\end{array}$ & $\begin{array}{c}\text { Cells/cu.mm } \\
\text {.blood(Mean } \pm \\
\text { Standard Error) }\end{array}$ & $\begin{array}{l}\text { Treatment } \\
\text { Efficiency } \\
(\%)\end{array}$ & $\begin{array}{c}\text { Statistical } \\
\text { Evaluation }\end{array}$ \\
\hline $\begin{array}{l}\text { itive Control } \\
\text { osphomide Drug) }\end{array}$ & 15 & $11700 \pm 1066$ & 45.3 & $\mathbf{A}$ \\
\hline $\begin{array}{l}\text { Control (Distilled } \\
\text { Water) }\end{array}$ & 0.00 & $8050 \pm 591$ & _- & $\mathbf{A}$ \\
\hline First dose & 250 & $12300 \pm 1047$ & 52.8 & $\mathbf{A}$ \\
\hline Second dose & 500 & $16850 \pm 9325$ & 109.3 & B \\
\hline Third dose & 750 & $19850 \pm 1372$ & 146.6 & $\mathrm{C}$ \\
\hline
\end{tabular}

Extracts

Different letters in the same column: significant difference $(\mathrm{P} \leq 0.05)$ between means.

\section{Differential count of leucocytes:}

Lymphocytes

The negative control (distilled water) showed lymphocyte count of 5054 cell/cu.mm blood, and such count was lower than the count in the positive control $(9370$ cell/cu.mm. blood). While, the second and third doses of (CCF) contributed to a significant increase in the counts of lymphocytes (14983 and 15701 cell/cu.mm. blood) as compared to negative control, with treatment efficiencies of $196.5 \%$ and $212.4 \%$ respectively, while a non-significant increase was shown at first doses (250 $\mathrm{mg} / \mathrm{kg}$ ) to reach 7904 cell/cu.mm blood as compared to the corresponding negative control Table (2).

Table (2): Total lymphocyte count (mean \pm standard error) in albino male mice treated with Lactobacillus acidophilus concentrated filtrate, distilled water (negative controls) and cyclophosphomide drug (positive control).

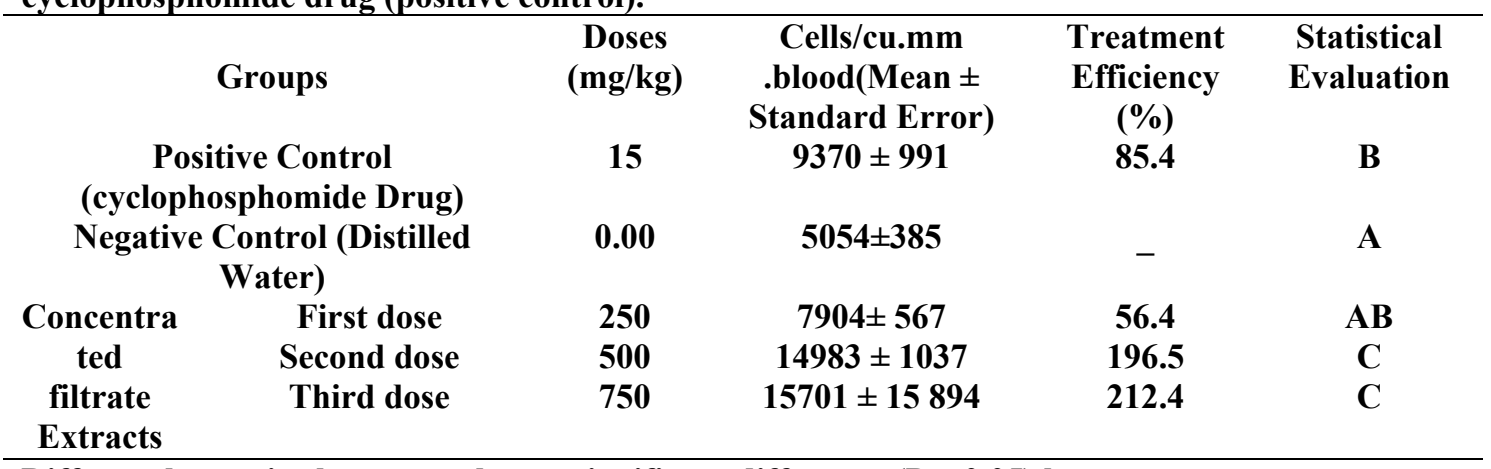

Different letters in the same column: significant difference $(\mathrm{P} \leq 0.05)$ between means.

\section{Neutrophils}

Animals of negative control group showed neutrophils count of $1995.5 \mathrm{cell} / \mathrm{cu} . \mathrm{mm}$. blood, and such count was higher than the count in the positive control(1460.5 cell/cu.mm. blood). The first dose of CCF increased the count of neutrophils to (3385.5 cell/cu.mm. blood) as compared to the corresponding negative control (1995.5 cell/cu.mm blood), however, the second and third dose of CCF showed none significant increase in the count of neutrophils (1284, 2947 cell/cu.mm. blood) respectively, as compared to negative control Table (3). 
Table (3): Total neutrophils count (mean \pm standard error) in albino male mice treated with Lactobacillus acidophilus concentrated filtrate, distilled water (negative controls) and cyclophosphomide drug (positive control).

\begin{tabular}{|c|c|c|c|c|}
\hline Groups & $\begin{array}{c}\text { Doses } \\
(\mathrm{mg} / \mathrm{kg})\end{array}$ & $\begin{array}{c}\text { Cells/cu.mm.blood } \\
\text { (Mean } \pm \text { Standard } \\
\text { Error })\end{array}$ & $\begin{array}{l}\text { Treatment } \\
\text { Efficiency } \\
\quad(\%)\end{array}$ & $\begin{array}{l}\text { Statistical } \\
\text { Evaluation }\end{array}$ \\
\hline $\begin{array}{c}\text { Positive Control } \\
\text { (cyclophosphomide Drug) }\end{array}$ & 15 & $1460.5 \pm 176$ & -26.8 & $\mathbf{A}$ \\
\hline $\begin{array}{c}\text { Negative Control (Distilled } \\
\text { Water) }\end{array}$ & 0.00 & $1995.5 \pm 88$ & - & $\mathbf{A}$ \\
\hline Concentrated $\quad$ First dose & 250 & $3385.5 \pm 535$ & 69.7 & B \\
\hline Second dose & 500 & $1284 \pm 188.8$ & -35.7 & $\mathbf{A}$ \\
\hline Third dose & 750 & $2947 \pm 548$ & 47.7 & $\mathbf{A B}$ \\
\hline
\end{tabular}

Different letters in the same column: significant difference $(\mathrm{P} \leq 0.05)$ between means.

\section{Monocytes}

The negative control showed a monocyte count of 849 cell/cu.mm blood, which was higher than the count of positive control (671 cell/cu.mm. blood), however such differences did not reach significant level. The first and third doses of CCF increased the count of monocytes which reached 980.5 and 1110 cell/cu.mm. blood, respectively, while the second dose decreased the count to 505 cell/cu.mm. blood as compared to the corresponding negative control, however, such differences did not reached a significant level as showed in Table (4).

Table (4): Total monocyte count (mean \pm standard error) in albino male mice treated with Lactobacillus acidophilus concentrated filtrate, distilled water (negative controls) and cyclophosphomide drug (positive control).

$\begin{array}{ccccc}\text { Groups } & \begin{array}{c}\text { Doses } \\ (\mathbf{m g} / \mathbf{k g})\end{array} & \begin{array}{c}\text { Cells/cu.mm.blood } \\ (\text { Mean } \pm \text { Standard Error })\end{array} & \begin{array}{c}\text { Treatment } \\ \text { Efficiency }(\%)\end{array} & \begin{array}{c}\text { Statistical } \\ \text { Evaluation }\end{array}\end{array}$

\begin{tabular}{cccccc}
\multicolumn{2}{c}{$\begin{array}{c}\text { Positive Control } \\
\text { (cyclophosphomide Drug) }\end{array}$} & 15 & $671 \pm 193$ & -27.3 & A \\
\multicolumn{2}{c}{ Negative Control (Distilled } & 0.00 & $849 \pm 122$ & - & A \\
Water) & First dose & $\mathbf{2 5 0}$ & $\mathbf{9 8 0 . 5} \pm 103$ & 15.5 & $\mathrm{~A}$ \\
$\begin{array}{c}\text { Concentrated } \\
\text { filtrate }\end{array}$ & Second dose & $\mathbf{5 0 0}$ & $\mathbf{5 0 5} \pm 114$ & -40.6 & $\mathrm{~A}$ \\
Extracts & Third dose & $\mathbf{7 5 0}$ & $\mathbf{1 1 1 0} \pm 99$ & $\mathbf{3 0 . 7}$ & $\mathrm{A}$ \\
\hline
\end{tabular}

Different letters in the same column: significant difference $(\mathrm{P} \leq 0.05)$ between means.

\section{Eosinophil and Basophil}

Animals of all treated groups showed no significant differences in the absolute counts of eosinophil and basophil (Table 5,6)

Table (5): Total eosinophils count (mean \pm standard error) in albino male mice treated with Lactobacillus acidophilus concentrated filtrate, distilled water (negative controls) and cyclophosphomide drug (positive control).

\begin{tabular}{|c|c|c|c|c|c|}
\hline \multicolumn{2}{|c|}{ Groups } & $\begin{array}{c}\text { Dose } \\
(\mathrm{mg} / \mathrm{kg})\end{array}$ & $\begin{array}{c}\text { Cells } / \text { cu.mm.blood } \\
\text { (Mean } \pm \text { Standard } \\
\text { Error) }\end{array}$ & $\begin{array}{l}\text { Treatment } \\
\text { Efficiency } \\
\quad(\%)\end{array}$ & $\begin{array}{l}\text { Statistical } \\
\text { Evaluation }\end{array}$ \\
\hline \multicolumn{2}{|c|}{$\begin{array}{c}\text { Positive Control } \\
\text { (cyclophosphomide Drug) }\end{array}$} & 15 & $84.5 \pm 43.6$ & -20.8 & $\mathbf{A}$ \\
\hline \multicolumn{2}{|c|}{ Negative Control (Distilled Water) } & $\mathbf{0 . 0 0}$ & $66.5 \pm 88.3$ & - & $\mathbf{A}$ \\
\hline Concentrated & First dose & 250 & & & $\mathbf{A}$ \\
\hline filtrate & Second dose & 500 & $39 \pm 39$ & $-5 \overline{3} .6$ & $\mathbf{A}$ \\
\hline Extracts & Third dose & 750 & $42.5 \pm 42.5$ & -49.4 & $\mathbf{A}$ \\
\hline
\end{tabular}

Different letters in the same column: significant difference $(P \leq 0.05)$ between means. 
Table (6): Total basophils count (mean \pm standard error) in albino male mice treated with Lactobacillus acidophilus concentrated filtrate, distilled water (negative controls) and cyclophosphomide drug (positive control).

\begin{tabular}{|c|c|c|c|c|c|}
\hline \multicolumn{2}{|c|}{ Groups } & $\begin{array}{c}\text { Dose } \\
(\mathrm{mg} / \mathrm{kg})\end{array}$ & $\begin{array}{c}\text { Cells/cu.mm.blood } \\
\text { (Mean } \pm \text { Standard } \\
\text { Error })\end{array}$ & $\begin{array}{c}\text { Treatment } \\
\text { Efficiency } \\
\quad(\%)\end{array}$ & $\begin{array}{l}\text { Statistical } \\
\text { Evaluation }\end{array}$ \\
\hline \multicolumn{2}{|c|}{$\begin{array}{c}\text { Positive Control } \\
\text { (cyclophosphomide Drug) }\end{array}$} & 15 & $114 \pm 49.9$ & 33.3 & $\mathbf{A}$ \\
\hline \multicolumn{2}{|c|}{$\begin{array}{c}\text { Negative Control (Distilled } \\
\text { Water) }\end{array}$} & 0.00 & $85.5 \pm 34.3$ & - & $\mathbf{A}$ \\
\hline Concentrate & First dose & 250 & $30 \pm 30$ & -69.9 & A \\
\hline d filtrate & Second dose & 500 & $49 \pm 49$ & -42.7 & $\mathbf{A}$ \\
\hline Extracts & Third dose & 750 & $42.5 \pm 42.5$ & -50.3 & $\mathbf{A}$ \\
\hline
\end{tabular}

Different letters in the same column: significant difference $(\mathrm{P} \leq 0.05)$ between means.

- Immunomodulatory effects of (CCF) of L. acidophilus:

Total count of leucocytes:

The pre-treatment group showed a significantly increased count of leucocytes as compared to the corresponding control (11550 vs. $6150 \mathrm{cell} / \mathrm{cu} . \mathrm{mm}$. blood), also the post -treatment enhanced the count significantly (13750 vs. 5700 cell/cu.mm. blood) Table (7).

Table (7): Total leucocyte count (mean \pm standard error) in albino male mice after interactions (pre- and post-treatments) between the ideal dose $(250 \mathrm{mg} / \mathrm{kg})$ of concentrated filtrate of Lactobacillus acidophilus and cyclophosphomide drug.

\begin{tabular}{|c|c|c|c|c|}
\hline \multirow{2}{*}{ Groups } & \multicolumn{2}{|c|}{$\begin{array}{c}\text { Cells/cu.mm .blood } \\
(\text { Mean } \pm \text { Standard Error })\end{array}$} & \multicolumn{2}{|c|}{ Treatment Efficiency (\%) } \\
\hline & $\begin{array}{l}\text { Pre- } \\
\text { treatment }\end{array}$ & $\begin{array}{c}\text { Post- } \\
\text { treatment }\end{array}$ & $\begin{array}{c}\text { Pre- } \\
\text { treatment }\end{array}$ & $\begin{array}{c}\text { Post- } \\
\text { treatment }\end{array}$ \\
\hline $\begin{array}{c}\text { Control (Distilled Water + } \\
\text { cyclophosphomide) }\end{array}$ & $6150 \pm 309.5^{a}$ & $5700 \pm 311$ & 0 & 0 \\
\hline $\begin{array}{l}\text { Concentrated } \\
\text { filtrate+cvclophosphomide }\end{array}$ & $11550 \pm 624 \quad b$ & $13750 \pm 298.5^{b}$ & 87.8 & 141.2 \\
\hline
\end{tabular}

Different letters in the same column: significant difference $(\mathrm{P} \leq 0.05)$ between means.

\section{Absolute count of leucocytes}

Lymphocytes:

The pre and post treatment with CCF was similar to each other in their effect on the lymphocytes count. The count was significantly increased in the pre-treatment as compared to the corresponding control (7512 vs. 4296 cell/cu.mm. blood) with a treatment efficiencies of $74.9 \%$. In the post treatment, the CCF was able to increase the count of lymphocytes significantly as compared to the corresponding control (10265 vs. 4935 cell/cu.mm. blood) with a treatment efficiency of $108 \%$ Table (8). 
Table (8): Total lymphocyte count (mean \pm standard error) in albino male mice after interactions (pre- and post-treatments) between the ideal dose $(750 \mathrm{mg} / \mathrm{kg})$ of concentrated filtrate of Lactobacillus acidophilus and cyclophosphomide drug.

\begin{tabular}{|c|c|c|c|c|c|}
\hline \multirow{2}{*}{ Groups } & \multicolumn{3}{|c|}{$\begin{array}{c}\text { Cells/cu.mm .blood } \\
\text { (Mean } \pm \text { Standard Error) }\end{array}$} & \multicolumn{2}{|c|}{ Treatment Efficiency $(\%)$} \\
\hline & $\begin{array}{c}\text { Pre- } \\
\text { treatment }\end{array}$ & & Post-treatment & $\begin{array}{c}\text { Pre- } \\
\text { treatment }\end{array}$ & $\begin{array}{c}\text { Post- } \\
\text { treatment }\end{array}$ \\
\hline $\begin{array}{l}\text { Control (Distilled Water }+ \\
\text { cyclophosphomide) }\end{array}$ & $4296 \pm 163.8$ & a & $4935 \pm 296.5^{a}$ & $\mathbf{0}$ & $\mathbf{0}$ \\
\hline $\begin{array}{c}\text { Concentrated } \\
\text { filtrate+cyclophosphomide }\end{array}$ & $7512 \pm 341.1$ & b & $10265 \pm 160$ & 74.9 & 108 \\
\hline
\end{tabular}

Different letters in the same column: significant difference $(P \leq 0.05)$ between means.

\section{Neutrophils:}

In the pretreatment interaction, the CCF was effective in increase the neutrophil count as compared to the corresponding control (2902 vs. 1563 cell/cu.mm. blood) with treatment efficiency $85.7 \%$, however such differences did not attend a significant level. In contrast, the post treatment with CCF showed a significant increase in the counts of neutrophil ( 2831 vs. 561 cell/cu.mm. blood) with a treatment efficiency of $404.8 \%$ Table (9).

Table (9): Total neutrophils count (mean \pm standard error) in albino male mice after interactions (pre- and post-treatments) between the ideal dose $(750 \mathrm{mg} / \mathrm{kg})$ of concentrated filtrate of Lactobacillus acidophilus and cyclophosphomide drug.

\begin{tabular}{|c|c|c|c|c|}
\hline \multirow{2}{*}{ Groups } & \multicolumn{2}{|c|}{$\begin{array}{l}\text { Cells/cu.mm .blood } \\
\text { (Mean } \pm \text { Standard Error) }\end{array}$} & $\begin{array}{l}\text { Treatment } \\
(\%)\end{array}$ & Efficiency \\
\hline & Pre-treatment & $\begin{array}{l}\text { Post- } \\
\text { treatment }\end{array}$ & $\begin{array}{l}\text { Pre- } \\
\text { treatment }\end{array}$ & $\begin{array}{l}\text { Post- } \\
\text { treatment }\end{array}$ \\
\hline $\begin{array}{l}\text { Control (Distilled } \\
\text { Water+cyclophosphomide) }\end{array}$ & $\begin{array}{l}1563 \pm 268.5 \\
\mathrm{a}\end{array}$ & $561 \pm 91$ & 0 & 0 \\
\hline $\begin{array}{l}\text { Concentrated } \\
\text { filtrate }+ \text { cyclophosphomide }\end{array}$ & $\begin{array}{l}2902 \pm 375.2 \\
\mathrm{a}\end{array}$ & $2831 \pm 315.7^{b}$ & 85.7 & 404.8 \\
\hline
\end{tabular}

Different letters in the same column: significant difference $(P \leq 0.05)$ between means.

\section{Monocytes;}

The post-treatment interaction showed no significant increase in monocyte count $(620$ vs. $268 \mathrm{cell} / \mathrm{cu} . \mathrm{mm}$. blood) with a treatment efficiencies of $151.2 \%$. The same picture was found in the pre-treatment interaction in which a non-significant increase in the count of monocytes was shown as compared to the corresponding control (782.5 vs. 311.5 cell/cu.mm. blood) Table (10). 
Table (10): Total monocytes count (mean \pm standard error) in albino male mice after interactions (pre- and post-treatments) between the ideal dose $(750 \mathrm{mg} / \mathrm{kg})$ of concentrated filtrate of Lactobacillus acidophilus and cyclophosphomide drug.

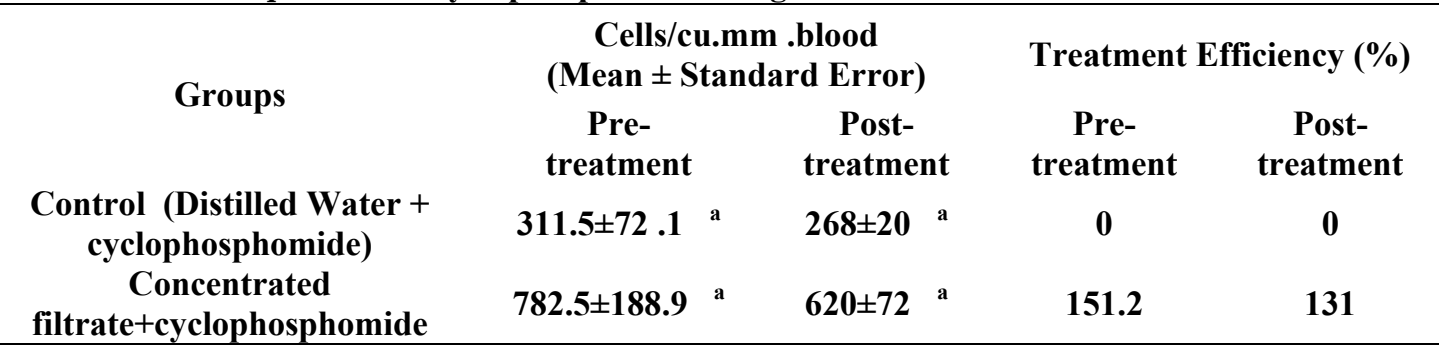

Different letters in the same column: significant difference $(P \leq 0.05)$ between means.

\section{Basophil and Eosinophil :}

Neither types of cells non the two types of treatment showed a significant differ Table $(11,12)$.

Table (11): Total basophils count (mean \pm standard error) in albino male mice after interactions (pre- and post-treatments) between the ideal dose $(750 \mathrm{mg} / \mathrm{kg})$ of concentrated filtrate of Lactobacillus acidophilus and cyclophosphomide drug.

\begin{tabular}{|c|c|c|c|c|}
\hline \multirow{2}{*}{ Groups } & \multicolumn{2}{|c|}{$\begin{array}{c}\text { Cells/cu.mm .blood } \\
\text { (Mean } \pm \text { Standard Error) }\end{array}$} & \multicolumn{2}{|c|}{ Treatment Efficiency (\%) } \\
\hline & $\begin{array}{c}\text { Pre- } \\
\text { treatment }\end{array}$ & $\begin{array}{c}\text { Post- } \\
\text { treatment }\end{array}$ & $\begin{array}{c}\text { Pre- } \\
\text { treatment }\end{array}$ & $\begin{array}{c}\text { Post- } \\
\text { treatment }\end{array}$ \\
\hline $\begin{array}{l}\text { Control (Distilled Water }+ \\
\text { cyclophosphomide) }\end{array}$ & $30 \pm 1735$ & - & $\mathbf{0}$ & $\mathbf{0}$ \\
\hline $\begin{array}{c}\text { Concentrated } \\
\text { filtrate+cyclophosphomide }\end{array}$ & $142.5 \pm 86$ & - & 375 & $\mathbf{0}$ \\
\hline
\end{tabular}

Different letters in the same column: significant difference $(\mathrm{P} \leq 0.05)$ between means.

Table (12): Total eosinophil count (mean \pm standard error) in albino male mice after interactions (pre- and post-treatments) between the ideal dose $(750 \mathrm{mg} / \mathrm{kg})$ of concentrated filtrate of Lactobacillus acidophilus and cyclophosphomide drug.

\begin{tabular}{|c|c|c|c|c|}
\hline \multirow{2}{*}{ Groups } & \multicolumn{2}{|c|}{$\begin{array}{c}\text { Cells/cu.mm .blood } \\
\text { (Mean } \pm \text { Standard Error) }\end{array}$} & \multicolumn{2}{|c|}{ Treatment Efficiency (\%) } \\
\hline & $\begin{array}{c}\text { Pre- } \\
\text { treatment }\end{array}$ & $\begin{array}{l}\text { Post- } \\
\text { treatment }\end{array}$ & $\begin{array}{l}\text { Pre- } \\
\text { treatment }\end{array}$ & $\begin{array}{c}\text { Post- } \\
\text { treatment }\end{array}$ \\
\hline $\begin{array}{l}\text { Control (Distilled Water + } \\
\text { cyclophosphomide) }\end{array}$ & $66.5 \pm 88.3$ & - & - & - \\
\hline $\begin{array}{c}\text { Concentrated } \\
\text { filtrate+cyclophosphomide }\end{array}$ & $119 \pm 4842$ a & - & - & - \\
\hline
\end{tabular}

Different letters in the same column: significant difference $(P \leq 0.05)$ between means.

\section{Discussion}

The results demonstrated that a treatment with Lactobacillus acidophilus concentrated filtrate had a significant effect on total and differential leucocytes count especially with the lymphocyte and neutrophils, which both showed a significant increase in their count. Neutrophils carry out important non-specific cellular defense mechanism, which is phagocytosis [15]. Probiotic bacteria such as Lactobacilli are known to play an important role in the maintenance of health by stimulating natural immunity and contributing to the balance of micro flora [16]. It is believed to positively affect the immune response by improving the intestinal microbial balance leading to enhanced antibody production and phagocytic (devouring or killing) activity of white blood cells. Neutrophils carry out important non-specific cellular defense mechanism, which is phagocytosis [17]. The increase in leucocytes count was much clear in the 
lymphocyte, which is considered as the important humeral and cellular arms of the adaptive immune response, and the filtrate may have exerted their effects on these cells $[18,19]$. The lymphocyte are of two main type, T and B lymphocytes, the T cells are further divided in to two functional type-helper $-1\left(\mathrm{~T}_{\mathrm{H}^{-}}-1\right)$ and $\left(\mathrm{T}_{\mathrm{H}^{-}}-2\right)$ which are based on the based on the profile of cytokines that they produce, and consequently each type is enhancing on arm of the immune response ; cell mediated and humeral immune responses, respectively [20]. On the other hand, Lactobacillus acidophilus may increase the activity of phagocytes and natural killer cells, it stimulates the cell to initiate the immune response and accelerating the immune system $\mathrm{s}$ ability to produce T- cell aggregation [21], or these increases may be due to compounds act as a regulator for proliferation and differentiation of bone marrow progenitor cell population [22], and also stimulates the mobilization of performed mature neutrophils from the bone marrow cavity or other pooling organs such as blood vessels [23] .

\section{References}

1. De Simone, C. R.; Vesely, B.; Bianchi, S. and Jirillo, E.(1993). The role of probiotics in modulation of the immune system in man and in animals. Int. J. Immunother. 9:23-28.

2. Link, H.; Rochat, F.; Saudan, K.Y. and Schiffrin. E. J.(1995). Immunomodulation of the gnotobiotic mouse through colonization with lactic acid bacteria. A. M. Immunology. 465-467.

3. Nadathur, S.; Gould, S. and Bakalinsky, A.(1994). Anti-mutagenicity of fermented milk. J. Dairy Sci. 77: 3287-3295.

4. Fuller, R. and Perdigon, G.(2000). Probiotics Immunomodulation by the gut microflora and probiotics. Fuller and Perdigon, eds. Kluwer Academic Publishers. Dordrecht.

5. Gilliland S.(1990). Acidophilus milk: A review of potential health benefits to consumer. J. Dairy Sci. 72: 2483-2494.

6. Gerritse, K.M.; Posno, M.M.; Schellekens, W.J.; Boersma, A. and Claassen, E.(1990). Oral administration of TNP-Lactobacillus conjugates in mice: a model for evaluation of mucosal and systemic immune responses and memory formation elicited by transformed lactobacilli. Res. Microbiol. 141:955.

7. Jankowsky, J.; Goodlad, R. and Wright, N.(1994). Mantenance of normal intestinal mucosa: function, structural and adaptation. Gut Supplement. 1: S1-S4.

8. Kaila, M.; Isolauri, E.; Soppi, E.; Virtanen, E.; Laine, S. and Arvilommi, H. (1992). Enhancement of the circulating antibody secreting cell response in human diarrhea by a human Lactobacillus strain. Pediatr. Res. 32: 141-144.

9. Hols, P.; Slos, P.; Dutot, P.; Reymund, J.; Chabot, P.; Delplace, B.; Delcour, J. and Mercenier, A.(1997). Efficient secretion of the model antigen M6-gp41E in Lactobacillus plantarum NCIMB 8826. Microbiol. 143: 2733-2741.

10. Jennings, R., Simms, J.R., and Heath, A.W.(1998). Adjuvants and delivery systems for viral vaccines-Mechanisms and potencial. In F. Brown and R.L. Haaheim, ed. Modulation of the immune response to vaccine antigens. Dev Biol Stand, Basel, Karger. 92: 19-28.

11. Iwaki, M.; Okahashi, N.; Takahashi, I.; Kanamoto, T.; Sugita-Konishi, Y.; Aibara, K. and Koga, T.(1990). Oral immunization with recombinant Strepococcus lactis carrying the Streptococcus mutans surface protein antigen gene. Infect. Immun. 58:2929.

12. Perdigon, G.; Nader de Macias, M.E.; Alvarez, S.; Oliver, G.; Pescede, A. A. and Ruiz Hogged, H.(1988). Systemic augmentation of the immune response in mice by feeding fermented milks with Lactobacillus casei and Lacrobacillus acidophilus. Immunology 63: 17. 
13. Sood, R.(1986). Haematology for Students and Practitioners. Jaypee Brothers, New Delhi, India.

14. Aiba Y.; Suzuki, N.; Kabir, A.M.; Takagi, A. and Koga, Y.(1998). Lactic acid mediated suppression of Helicobacter pylori by the oral administration of Lactobacillus salivarins as a probiotic in agnotobiotic marine model. Am. J. Gastroenterol. 93: 2097-2101.

15. Solis Pereyra, B. and Lemonnier, D.(1991). Induction of 2'-5' A synthase activity and interferon In humans by bacteria used in dairy products. Eur. Cytokine. Net. 2: 137.

16. Fernandes, C.F.; Shahani, K.M.; Staudinger, W.L. and Amer M.A.(1991). Mode of tumor suppression by Lactobacillus acidophilus. J. Nutr. Medicine, 2:25-34.

17. Abbas, A.K. and Lichtman, A.H. (Editors) (2003). Cellular and Molecular Immunology, $5^{\text {th }}$ Edition. Elsevier Science (U.S.A.) pp. 1-16.

18. Cole, A.S.; Eastoe, J.E.; Mcgivan, J.;Hayes, M.L. and Smillie, A.C. (1998). Biochemistry and Biology, $2^{\text {nd }}$ Edition, London, pp.156-169.

19. Moller, P. and Loft, S. (2002). Oxidative DNA damage in human white blood cells in dietary antioxidant intervention studies. American Journal of Clinical Nutrition, 76: 303-310.

20. Roitt,I.;Brostoff,J. and Male ,D.(2001).Immunology . $6^{\text {th }}$ ed. Chapter 8.Mosby.

21. Chu, D.; Sun,Y.; Lin, J.; Wong, W.; and Mavligit, G. (1990) . F3, afractionated extract of Astragalus membranaceus, potenta by low dose recombinant interleukin-2. Chung Hsil Chieh Ho Tsa Chih, 10: 34-6 .

22. Clark, S.C.; and Kamen, R. (1987). The human hematopoietic colony stimulating factors. Science, 236: 1229-1237.

23. Okabe,M; Asano,M.; Kuga ,T.; Komatsu,Y.; Yamasaki „M; Yokoo , Y.; Itoh,S.; Morimoto,M.; and Oka, T. (1990) . In vitro and in vivo hematopoietic effect of mutant human granulocyte colony stimulating factor . Blood, 75: 1788-1793. 